http://heanoti.com/index.php/hn

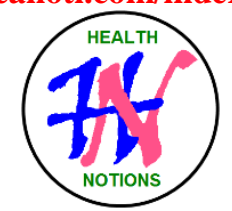

RESEARCH ARTICLE

URL of this article: http://heanoti.com/index.php/hn/article/view/hn30104

\title{
An Effectiveness Emla Used on School Aged Children's Level of Pain During Venipuncture Procedure in Hospital
}

\author{
Tri Sakti Widyaningsih ${ }^{1(\mathrm{CA})}$, Dwi Nur Aini $^{2}$ \\ ${ }^{1(C A)}$ Department of Nursing, STIKes Widya Husada Semarang, Indonesia; imoet.sakti@gmail.com \\ (Corresponding Author) \\ ${ }^{2}$ Department of Nursing, STIKes Widya Husada Semarang, Indonesia; dwi.nuraini00@gmail.com
}

\begin{abstract}
Pain that is not immediately cultivated can have a detrimental effect on children, including anxiety, sleep difficulties and despair. A child takes a series of procedures in a Hospital as a therapy. The first procedure often used on a child as he/she enters a hospital will be an intravenous therapy procedure and blood collection venipuncture. A topical anesthesia is often used in pediatric care. EMLA cream is an option to reduce pain during a venipuncture procedure on children. The research aims at know how the effectiveness of EMLA used on school aged child's level of pain during venipuncture in Hospital. The research method of study used a quasi experimental post-test only non-equivalent control group. The sampling technique used consecutive sampling with a sample of 30 respondents consisted of two groups (intervention and control group). Bivariate analysis was carried out of using the Mann Withney test. The results indicated level of pain of children in the intervention group the majority experienced hurt little more $5.07 \%$. The pain level in the majority control group experienced $8.53 \%$ is hurt worst. Based on the results of the study obtained a significant value was $0.000(\mathrm{p}<0.05)$, it means that Ho was rejected and Ha was accepted which means that there was an effect of EMLA on the level of pain during infusion installation in children in hospital (RSUD dr. H Soewondo Kendal).
\end{abstract}

Keywords: EMLA, Pain, Venipuncture

\section{INTRODUCTION}

\section{Background}

Disease and hospitalization often cause stress on children. These are often the first crisis every child needs to deal with. Hockenberry and Wilson explain that during hospitalization, children are stressful as the result of change to their health, different environmental routine and their limited coping mechanism to encounter stressor. One of the main hospitalization stressors on children is pain which affects their traumatic feeling. Therefore, children need to be prepared for dealing with hospitalization experience and various procedures, primarily ones with pain.

An observational research on children and adolescents reports that adolescents and pre-adolescents (school age children) bear the highest level of pain during venipuncture procedure. The research results report that $13 \%$ of 171 of 7-17 years old children feel medium to severe pain from venipuncture. Nearly $50 \%$ of children of this range feel the highest distress during venipuncture procedure ${ }^{(1)}$.

Biran et al. study the effectiveness of EMLA combined with sucrose in reducing pain during venipuncture procedure on children. The research results show that there is significant difference, that the group of children with EMLA feels more than the group of children with combined EMLA and sucrose. The research concludes that combined EMLA and sucrose are recommended for children exposed to venipuncture procedure ${ }^{(2)}$.

Pain assessment and management during children hospitalization are nurse's role and responsibility. 332 patients under care in Dahlia Room, RSUD Dr. H Soewondo are collected in the introductory study. According to the Medical Record of RSUD Dr. H Soewondo Kendal, the pain levels distribution on 28 respondents when infusion is installed from January-March 2017 is as follows: no pain (0\%), mild pain (0\%), slightly moderate pain $(0 \%)$, moderate pain $(25 \%)$, severe pain $(32.1 \%)$, and exceptionally severe pain $(42.9 \%)^{(3)}$. 
While conducting a venipuncture procedure, a nurse has conducted any effort to reduce child's pain and anxiety even if not all techniques are implemented according to theory. The nurse will try to reduce the pain by involving child's parents during procedure, guiding the child to pray before venipuncture process, conducting relaxation technique for the older child and giving cold stimulus on the skin using alcohol or ice. Pain reducing technique for venipuncture such as using EMLA has never been implemented by a nurse.

On the background above, the writer is interested in studying the Effectiveness EMLA used on school aged children's level of pain during venipuncture in Hospital (RSUD H. Soewondo, Kendal).

\section{Purpose}

This research aims at know how the effectiveness of EMLA used on school aged children's level of pain during venipuncture in hospital (RSUD H Soewondo, Kendal).

\section{METHODS}

The research method of study used a quasi experimental post-test only non-equivalent control group ${ }^{(4)}$. This research was implemented in Dahlia Room, RSUD Dr H Soewondo, Kendal in April - May 2018. The sampling technique used consecutive sampling with a sample of 30 respondents consisted of two groups (intervention and control group). Bivariate analysis was carried out of using the Mann Withney test.

In this research, the researchers strongly refer to the scientific attitudes and implement the nursing research ethical principles. The researchers believe that the respondents are well protected considering to the aspects of self determination, privacy, anonymity, informed consent, and protection from discomfort ${ }^{(5)}$. The researchers have provided adequate time and opportunities for the respondents to think and understand the research objective that the decision made may reflect their self awareness without any force. The respondents state their willingness to sign the form of informed consent given by the researchers. The information collected and the treatment given by the researchers to the respondents were conducted by appreciated respondents as the respected individuals. In this research, the respondents' names were confidential and replaced with the respondents' number coding. All respondents were treated equally during the research processes. All respondent were given the same intervention with physical exercise. The researchers first asked the agreement from the respondents. The researchers provide the explanations covering objective, exercise benefits, risk, and discomfort from the intervention as well as the researchers' hope to the respondents. After the respondents understand all the given explanations, the researchers asked the respondents' willingness to sign the letter of agreement to become the research subject. The discomfort resulted from the treatments given by the researchers were well anticipated. The researchers assert that if the respondents feel insecure and discomfort with the physical exercise given, the intervention was better stopped immediately.

\section{RESULTS}

The results in EMLA group's level of pain showed that 53.3\% of EMLA group respondents felt moderate pain and $46.7 \%$ respondents feel slightly moderate pain. No respondent from any group felt exceptionally severe pain. The results in Controls Group's level of pain showed that $60 \%$ of Controls group respondents felt severe pain, $33.3 \%$ respondents felt exceptionally severe and $6.7 \%$ respondents felt moderate pain.

Table 1. Level of Pain Distribution in EMLA Group in Dahlia Room, RSUD H Soewondo, Kendal from April to May 2018

\begin{tabular}{ccc}
\hline Level of Pain & \multicolumn{2}{c}{ EMLA Group } \\
\cline { 2 - 3 } & $\mathrm{n}$ & 0 \\
\hline No Pain & 0 & 0 \\
Mild Pain & 0 & 46.7 \\
Slightly Moderate Pain & 7 & 53.3 \\
Moderate Pain & 8 & 0 \\
Severe Pain & 0 & 0 \\
Exceptionally Severe Pain & 0 & 100 \\
\hline Total & 15 &
\end{tabular}

19 | Publisher: Humanistic Netwark far Science and Technology 
Based on the results of the study obtained a significant value $\mathrm{p}$ value was $0.000(\mathrm{p}<0.05)$, it means that Ho was rejected and Ha was accepted which means that there was an effect of EMLA on the level of pain during infusion installation in children in hospital (RSUD dr. H Soewondo Kendal)

Table 2. Level of Pain Distribution in Controls Group in Dahlia Room, RSUD H Soewondo, Kendal from April to May 2018

\begin{tabular}{lll}
\hline Level of Pain & \multicolumn{2}{l}{ EMLA Group } \\
\cline { 2 - 3 } & $\mathrm{n}$ & $\%$ \\
\hline No Pain & 0 & 0 \\
Mild Pain & 0 & 0 \\
Slightly Moderate Pain & 0 & 0 \\
Moderate Pain & 1 & 6.7 \\
Severe Pain & 9 & 60 \\
Exceptionally Severe Pain & 5 & 33.3 \\
\hline Total & 15 & 100 \\
\hline
\end{tabular}

Table 3. Distribution of Level of Pain Difference between EMLA Group and Controls Group in Dahlia Room, RSUD H Soewondo, Kendal from April to May 2018

\begin{tabular}{cccccc}
\hline Groups & $\mathrm{n}$ & Min-Max & Mean & SD & $p$ \\
\cline { 1 - 4 } EMLA group & 15 & $4-6$ & 5.07 & 1.033 & 0.000 \\
\cline { 1 - 4 } Control & 15 & $6-10$ & 8.53 & 1.187 & \\
\cline { 1 - 4 } Total & 30 & & & &
\end{tabular}

\section{DISCUSSION}

The analysis outcome shows that most of the children are female. Considerable amount of patients of a gender is often associated to morbidity risk group. Higher number of female pediatric patients as the respondents indicates that more female children are treated than male children and female children are the morbidity risk group. Meanwhile, according to Hockenberry and Wilson (2009), male children are of morbidity risk group. This difference can be base of the analysis and there may be other factor causing female pediatric patients higher in number than male pediatric patients such as higher number of female population in an area, higher number of male infants or children death and people's culture. No supporting data are available to explain higher number of female children in the research. Previous experience and family support are factors which may influence children's level of pain during procedure ${ }^{(6)}$.

The research outcome shows that generally the children that 53.3\% of EMLA group respondents feel moderate pain and $46.7 \%$ respondents feel slightly moderate pain. No respondent from any group feels exceptionally severe pain. The reason of this is that the data are collected from a care unit and used something with reduce pain before venipuncture procedurs.

The research outcome shows that almost all of the children that $60 \%$ of Controls group respondents feel severe pain, $33.3 \%$ respondents feel exceptionally severe and $6.7 \%$ respondents feel moderate pain, the reason this because the children not used EMLA before it. Other than that the parents/caretakers want to accompany their children during venipuncture procedure. Pain is a condition caused by individual certain and subjective stimulus ${ }^{(6)}$.

The research outcome shows that most of the children feel mild pain and slightly moderate pain in both groups. From distribution perspective, pain level of both groups are more different, this proves that using EMLA is an option to reduce pain during venipuncture procedure. According to Hockenberry and Wilson, EMLA 
techniques is directly reducing pain on local area. The research outcome illustrates that EMLA technique have different from the controls group without $\mathrm{EMLA}^{(1)}$.

The research has identified the level of pain in EMLA group, with Based on the results of the study obtained a significant value was $0.000(\mathrm{p}<0.05)$, it means that Ho was rejected and Ha was accepted which means that there was an effect of EMLA on the level of pain during infusion installation in children in hospital (RSUD dr. H Soewondo Kendal). This showed that EMLA was an analgesic therapy that can reduce pain. According to Supartini, using EMLA cream takes time for it to diffuse into dermal and epidermal skin layers, which eventually results in local accumulation in end and pain receptor regions ${ }^{(7)}$. A Neural Research has indicated that how EMLA affects level of pain depends on to what extent EMLA cream was diffused into pain receptor. A previous research conducted by Weinstening concludes that local cold compress administration significantly changes children's pain physiological response in venipuncture procedure ${ }^{(10)}$. Cold compress physiological effect can reduce pain by having the area anesthetized, showing down the flow of pain impulse and increasing pain threshold ${ }^{(8)}$.

This research outcome was in line with a research conducted by Wahyuni with regard to an effectiveness comparison between EMLA cream and cold compress to pain response using an ocher scale ${ }^{(9)}$. A previous research compares the average score of pain intensity of EMLA with a control group. A statistical test outcome shows that there was no significant difference between pain intensity of EMLA group and local cooling ( $>00.05$ ). Wahyuni concludes that local cooling in a venipuncture procedure was an alternative therapy that can be administered to children before venipuncture procedure ${ }^{(9)}$.

Based on duration, pain felt by children during a venipuncture procedure was an acute pain. Acute pain occurs when the pain was lost only within some expected periods ${ }^{(2)}$. The half-life of lidocaine contained in EMLA was 7-30 minutes in the first phase and 90-120 minutes in the final phase, while that of prilocaine was 10-50 minutes $^{(7)}$. Therefore, using a topical drug of EMLA was timely limited in reducing pain, which was better used for reducing acute pain.

Based on the researcher's observation during the research, some children of EMLA group were found requesting for re-intervention when a blood sampling venipuncture procedure was to be conducted. The children state that they are comfortable when injected and not bothered even if they have to wait for 45 minutes for the procedure. This is an advantage of EMLA administration to be applied to children.

Using EMLA has some weaknesses. A nurse comments on the use of EMLA during the research, stating that EMLA cannot be administered for all patients in any condition. They prefer using cold compress to EMLA on the reason that it was easier to be used, cheap and requires little time.

Pain management using EMLA affects children to tolerate pain resulted from a venipuncture procedure.

\section{CONCLUSION}

There is an effect of EMLA on the level of pain during infusion installation in children in hospital (RSUD dr. H Soewondo Kendal).

\section{REFERENCES}

1. Hockenberry M, Wilson. Wong's Essensials of Pediatric Nursing. St.Louise Missouri: Mosby Essiver; 2009

2. Lewis S, Dirksen S, Heitkemper M, Bucher L, Camera I. Medical-Surgical Nursing. 8 th Ed. Elvier: New York; 2011.

3. RSUD Dr. H. Soewondo Kendal. Medical Record. Kendal: RSUD Dr. H Soewondo Kendal; 2017.

4. Dharma KK. Nursing Research Methodology: A Guidance to Perform and Implement the Research Results (Metodologi Penelitian Keperawatan: Pedoman Melaksanakan dan Menerapkan Hasil Penelitian). Jakarta: CV Trans Info Media; 2011.

5. Nursalam. Concept and Implementation of Nursing Sciences Research Methodology: A guidance for Nursing Final Project, Thesis, and Research Instrument (Konsep dan Penerapan Metodologi Penelitian Ilmu Keperawatan; Pedoman Skripsi, Tesis, dan Instrument Penelitian Keperawatan). Jakarta: Salemba Medika; 2008.

6. Potter PA, Perry AG. Fundamentals of Nursing. Sixth Edition. Philadelphia: Mosby Inc; 2005.

7. Supartini Y. A Textbook: Basic Concept for Children Nursing (Buku Ajar: Konsep Dasar Keperawatan Anak). Jakarta: EGC; 2004.

8. Smelzer SC, Bare BG. A Textbook for Medical Surgery Nursing of (Buku Ajar Keperawatan Medical Bedah). Brunner \& Suddarth. Jakarta:EGC; 2002.

9. Wahyuni NS, Nurhidayat S. The Effectiveness of Compress Application to Reduce the Phlebitis Pain Resulted from the Installation of Intervene Line (Efektifitas Pemberian Kompres terhadap Penurunan Nyeri Phlebitis Akibat Pemasangan Intravena Line). Fenomena. 2008;5(2).

21 | Publisher: Humanistic Network far Science and Technology 
10. Weinstening SM. Complication and Intervention. In Plum's Principle and Practice of Intervenous Therapy. ( ${ }^{\text {th }}$ ed). Philadhelpia: Lippiccott Williams \& Wilkins; 2007. 